\title{
Raman, Visible and Ultra-violet Spectral Studies of Ionic Interactions in Molten Alkali Nitrate and Nitrite Systems
}

\author{
Kazuo Sakai* and Tetsurō Nakamura \\ Research Laboratory of Engineering Materials, Tokyo Institute of Technology, \\ 4259 Nagatsuta, Midoriku, Yokohama 227, Japan
}

Z. Naturforsch. 40a, 892-902 (1985); received March 9, 1985

The interaction between the various ions in the molten systems $\mathrm{NaNO}_{3}-\mathrm{NaNO}_{2}$, $\mathrm{LiNO}_{3}-\mathrm{NaNO}_{2}$ and $\mathrm{NaNO}_{3}-\mathrm{KNO}_{2}$ has been investigated by Raman, visible and ultraviolet absorption spectroscopy. It is concluded that the interaction between the anions is very weak and that the cations $\mathrm{Na}^{+}$and $\mathrm{K}^{+}$are randomly distributed around the nitrate and nitrite anions. The empty orbital level of $\mathrm{Na}^{+}(434 \mathrm{~nm})$ in $\mathrm{NaNO}_{3}-\mathrm{NaNO}_{2}$ relative to the $\pi$ level of $\mathrm{NO}_{2}^{-}$is estimated. When small amounts of $\mathrm{Li}^{+}$are added to the binary sodium melt, an anomalous spectroscopic result is obtained.

The structure and other physical properties of molten nitrate and nitrite systems have already been studied extensively by means of calorimetry [1-5], gravimetry [6], X-ray diffraction [7, 8], Raman spectroscopy [9-21], and visible and ultraviolet absorption spectroscopy [22, 23]. An investigation of the interaction between the anions in a molten system containing nitrate and iodate has also been reported [24].

However, few molten nitrate-nitrite systems, additive [25] or reciprocal [26], have been investigated. Therefore we have studied the ionic interaction in the molten systems $\mathrm{NaNO}_{3}-\mathrm{NaNO}_{2}$, $\mathrm{LiNO}_{3}-\mathrm{NaNO}_{2}$ and $\mathrm{NaNO}_{3}-\mathrm{KNO}_{2}$ by means of Raman, visible and ultraviolet absorption spectroscopy.

\section{Experimental}

The nitrates $\mathrm{ANO}_{2}(\mathrm{~A}=\mathrm{Li}, \mathrm{Na}, \mathrm{K} ; 99.9 \%)$ were dehydrated in vacuo at about $40^{\circ} \mathrm{C}$ for several days. Then we examined the $\mathrm{ANO}_{3}$ purity and the absence of nitrate $\left(820 \mathrm{~cm}^{-1}\right.$ for $\left.\mathrm{NO}_{2}^{-}\right)$by Raman spectroscopy. In the same manner the nitrites $\mathrm{BNO}_{2}$ $(\mathrm{B}=\mathrm{Na}, \mathrm{K})$ were dehydrated after recrystallization.

\footnotetext{
* Present address: Electronics Materials Laboratory, Sumitomo Metal Mining Co., Ltd., Suehirocho, Ohme, Tokyo 198, Japan.

Reprint requests to Prof. T. Nakamura, Research Laboratory of Engineering Materials, Tokyo Institute of Technology, 4259 Nagatsuta, Midoriku, Yokohama 227, Japan.
}

A single crystal of $\mathrm{NaNO}_{2}$ was grown via the StockBarger method. But we failed to obtain single crystals of $\mathrm{LiNO}_{2}$ and $\mathrm{KNO}_{2}$. Therefore, we repeated the recrystallization and dehydration several times, put the samples into an alumina crucible and kept them under argon just above the melting point for $2 \mathrm{hrs}$. Again the nitrite purity was examined by Raman spectroscopy.

The purified nitrates and nitrites were mixed in the desired ratios in a dry box. Then the sample were transferred into the furnance in argon atmosphere and the temperature was raised just above the melting temperature. A part of the fused sample was transferred into the quartz Raman cell. After the temperature was decreased, the Raman cell was sealed off in vacuo.

The Raman spectra were recorded at $360^{\circ} \mathrm{C}$ by a JEOL spectrometer with $514.5 \mathrm{~nm}$ excitation (ca. $300 \mathrm{~mW}$ ) of an Ar ion Laser (Spectra Physics). To analyze in detail we recorded over three ranges: $650-850 \mathrm{~cm}^{-1}, \quad 1000-1100 \mathrm{~cm}^{-1}$ and $1100-1600$ $\mathrm{cm}^{-1}$. For the $1000-1100 \mathrm{~cm}^{-1}$ range the spectral slit width was fixed at $1.5 \mathrm{~cm}^{-1}$, for the other ranges, at $3 \mathrm{~cm}^{-1}$. Each range was scanned for $50 \mathrm{~min}$. The calibration was carried out by using Neon lines.

Visible (VIS) and ultraviolet (UV) absorption spectra were recorded with a single beam JASCOSS 50 spectrophotometer using quartz sample cells placed in an electric furnace. Samples of nitrate and nitrite in the appropriate molar ratio were mixed 


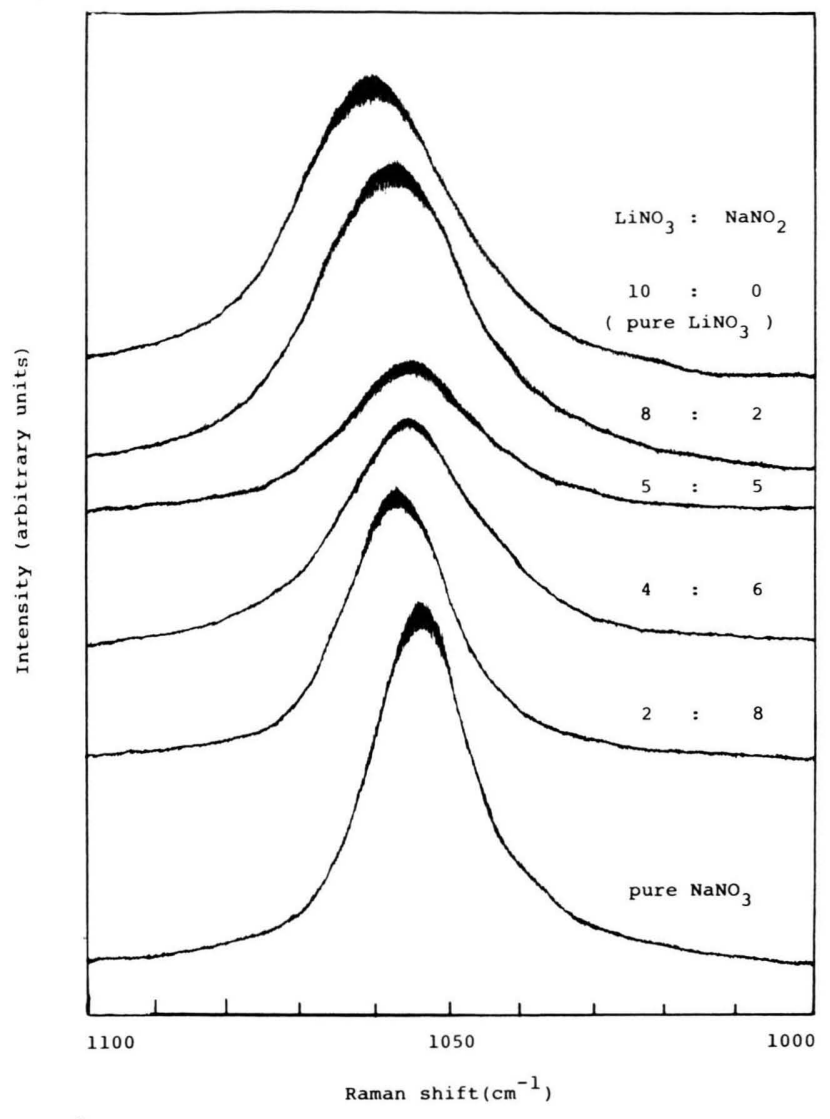

a)

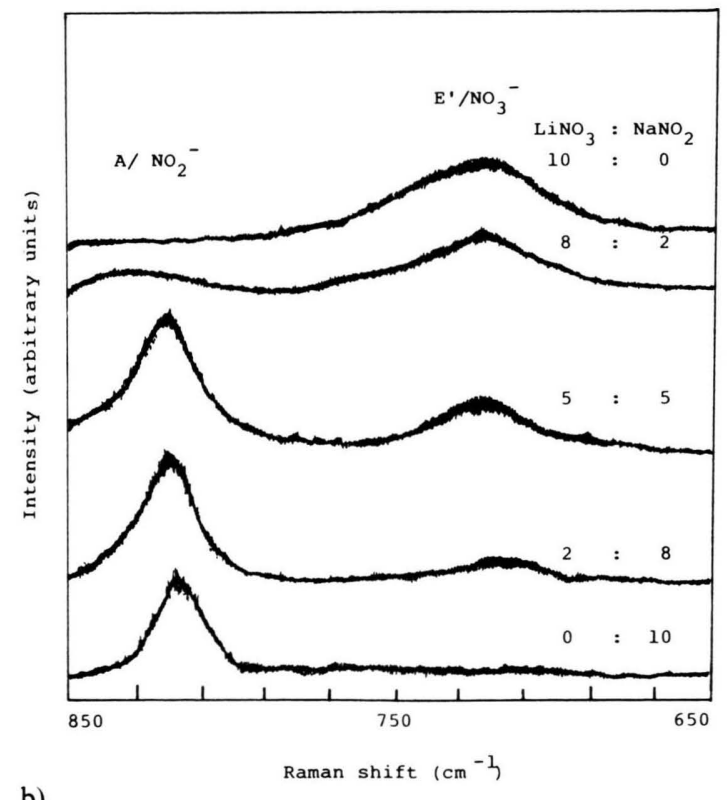

b) and ground to fine powder in an Argon atmosphere, transferred into the quartz sample cell and sealed off in vacuo. Then the quartz cell was placed in the furnace. After recording reference spectra (back ground spectra of the empty part of the quartz cell) the nitrate-nitrite mixtures were equilibrated and the VIS and UV spectra measured. A Tungsten lamp was used as light source for the VIS and a Xenon lamp for the UV absorption measurements. The UV spectrometer arrangement was always purged with dried $\mathrm{N}_{2}$.

\section{Results}

Figures $1 \mathrm{a}-\mathrm{c}$ show the Raman spectra of the $\mathrm{LiNO}_{3}-\mathrm{NaNO}_{2}$ melts. The composition changes of the $\mathrm{A}_{1}^{\prime}$ mode of $\mathrm{NO}_{3}^{-}$in the range of $1000-1100$ $\mathrm{cm}^{-1}$ are shown in Figure $1 \mathrm{a}$. In a similar way, both the $E^{\prime}\left(v_{3}\right)$ mode of $\mathrm{NO}_{3}^{-}$and the $\mathrm{A}$ mode of $\mathrm{NO}_{2}^{-}$in the range of $650-850 \mathrm{~cm}^{-1}$ are shown in Fig. $1 \mathrm{~b}$ and, moreover, the $E^{\prime}$ mode $\left(v_{4}\right)$ of $\mathrm{NO}_{3}^{-}$and the $\mathrm{A}$ and $\mathrm{B}$ modes of $\mathrm{NO}_{2}^{-}$in the range of $1100-1600$ $\mathrm{cm}^{-1}$ are shown in Figure $1 \mathrm{c}$. Figures $2 \mathrm{a}-\mathrm{c}$ show Raman shifts vs. composition of $\mathrm{LiNO}_{3}-\mathrm{NaNO}_{2}$,

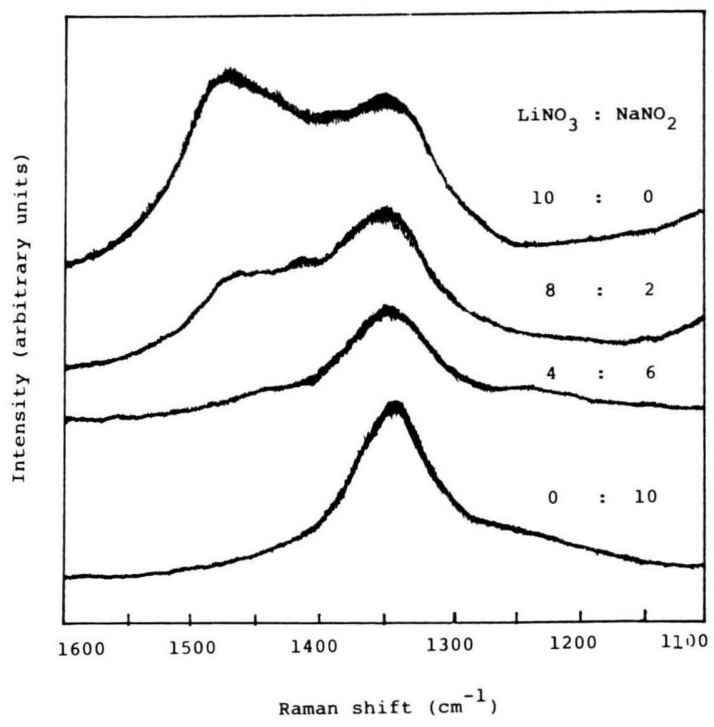

c)

Fig. 1. Raman spectra for various $\mathrm{LiNO}_{3}: \mathrm{NaNO}_{2}$ ratios. a) $\mathrm{A}_{1}^{\prime}$ mode of $\mathrm{NO}_{3}^{-}$; b) $E^{\prime}$ mode of $\mathrm{NO}_{3}^{-}$and $\mathrm{A}$ mode of $\mathrm{NO}_{2}^{-}$; c) overlapping spectra of $E^{\prime}$ mode of $\mathrm{NO}_{3}^{-}$and $\mathrm{A}$ and $\mathrm{B}$ modes of $\mathrm{NO}_{2}^{-}$. 

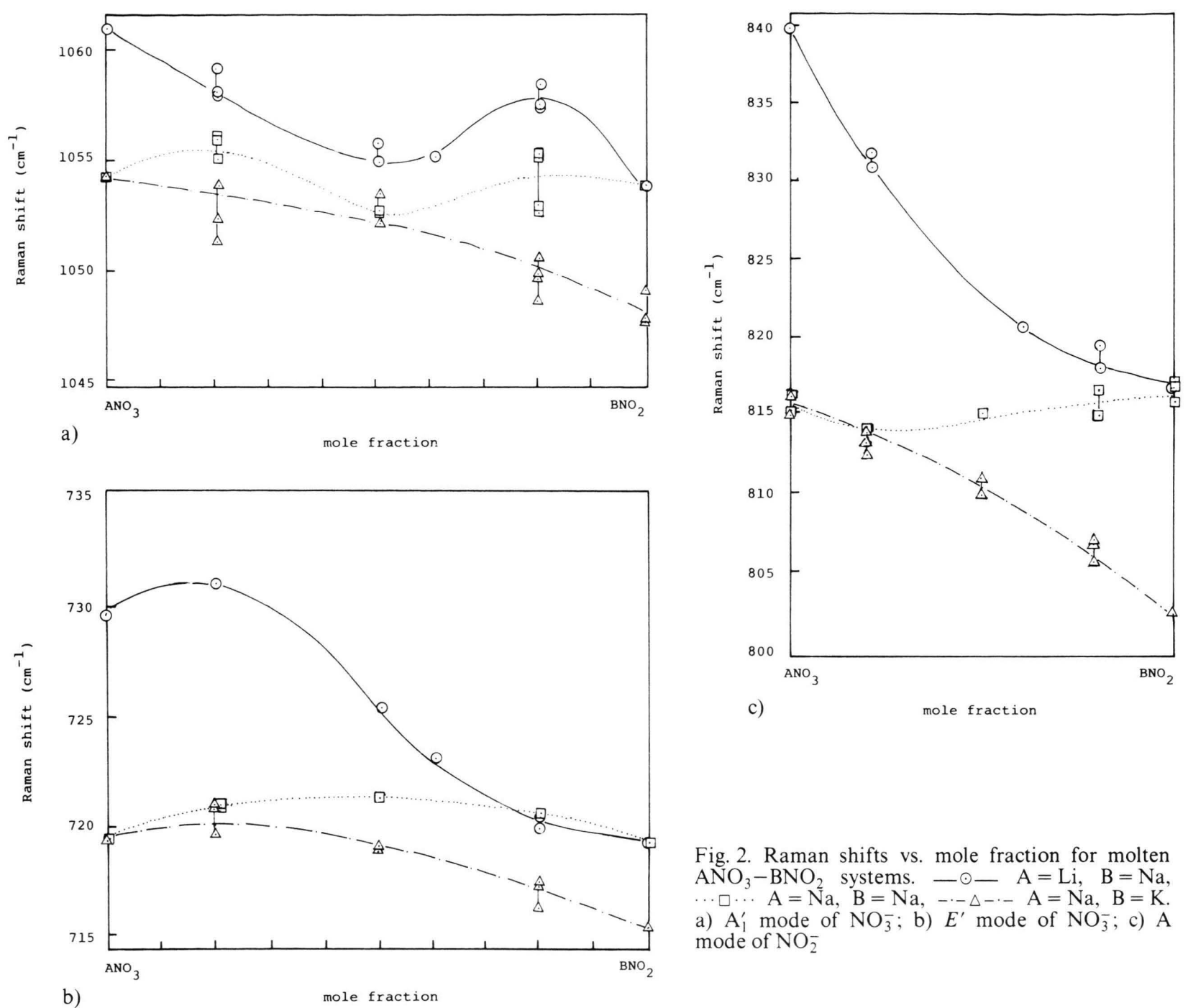

Fig. 2. Raman shifts vs. mole fraction for molten $\mathrm{ANO}_{3}-\mathrm{BNO}_{2}$ systems. - $\odot-\mathrm{A}=\mathrm{Li}, \mathrm{B}=\mathrm{Na}$, $\cdots \square \cdot A=\mathrm{Na}, \mathrm{B}=\mathrm{Na},-\cdot-\cdot-\cdot \mathrm{A}=\mathrm{Na}, \mathrm{B}=\mathrm{K}$ a) $\mathrm{A}_{1}^{\prime}$ mode of $\mathrm{NO}_{3}^{-}$; b) $E^{\prime}$ mode of $\mathrm{NO}_{3}^{-}$; c) $\mathrm{A}$ mode of $\mathrm{NO}_{2}^{-}$

$\mathrm{NaNO}_{3}-\mathrm{NaNO}_{2}$ and $\mathrm{NaNO}_{3}-\mathrm{KNO}_{2}$ melts. The half widths of the $\mathrm{A}_{1}^{\prime}$ mode of $\mathrm{NO}_{3}^{-}$are shown in Figure 3. Figures $4 a-c$ are examples of the deconvolution of bands by use of the non-linear least squares method with Voigt function [27], which is given by

$$
V(\tilde{v})=\int_{-\infty}^{+\infty} \frac{\beta_{1} / \pi}{\beta_{1}^{2}+\left(\tilde{v}-v^{\prime}\right)^{2}} \frac{1}{\sqrt{\pi \beta_{\mathrm{g}}}} \exp \left(-v^{\prime} / \beta_{\mathrm{g}}\right) \mathrm{d} v^{\prime} .
$$

Here, $\beta_{1}$ and $\beta_{\mathrm{g}}$ are half widths of Lorentzian and Gaussian functions, respectively. The relative peak intensity $I$, the peak center $\tilde{v}\left(\mathrm{~cm}^{-1}\right)$ and the half width $\beta_{1}\left(\mathrm{~cm}^{-1}\right)$ for individual Raman bands, separated into each Raman active mode by means of the above method, are tabulated in Table 1. The calculated force constants of $\mathrm{NO}_{3}^{-}$using a UreyBradley potential are shown in Table 2.

The changes of the VIS absorption with composition of molten $\mathrm{NaNO}_{3}-\mathrm{NaNO}_{2}$ at $360{ }^{\circ} \mathrm{C}$ are shown in Figure 5. Figures $6 a-b$ show VIS and UV absorption spectra, respectively, at various temperatures for the molar ratio $\mathrm{NaNO}_{3}: \mathrm{NaNO}_{2}=5: 5$.

The absorption at $240 \mathrm{~nm}$ in Fig. $6 \mathrm{~b}$ is due to the transiton from the $\pi$-orbital of $\mathrm{NO}_{3}^{-}$to the empty orbital of $\mathrm{Na}^{+}$. This absorption clearly indicates "red shift" with temperature increase. Rhodes and 
Table 1. Raman shifts $\tilde{v}$, relative intensities $I$, and half widths $\beta_{1}$ of Raman active modes of $\mathrm{NO}_{3}^{-}$and $\mathrm{NO}_{2}^{-}$for various $\mathrm{ANO}_{3}: \mathrm{BNO}_{2}$ ratios $[(\mathrm{A}, \mathrm{B})=(\mathrm{Li}, \mathrm{Na}),(\mathrm{Na}, \mathrm{Na}),(\mathrm{Na}, \mathrm{K})]$. Capitals $\mathrm{Q}$ and $\mathrm{P}$ in the second column denote: Obtained by use of a quartz sample cell and a platinum basket cell, respectively. The symbol \# denotes "impossible to compare"; the symbols - and * denote "no modes expected" and "failed to observe".

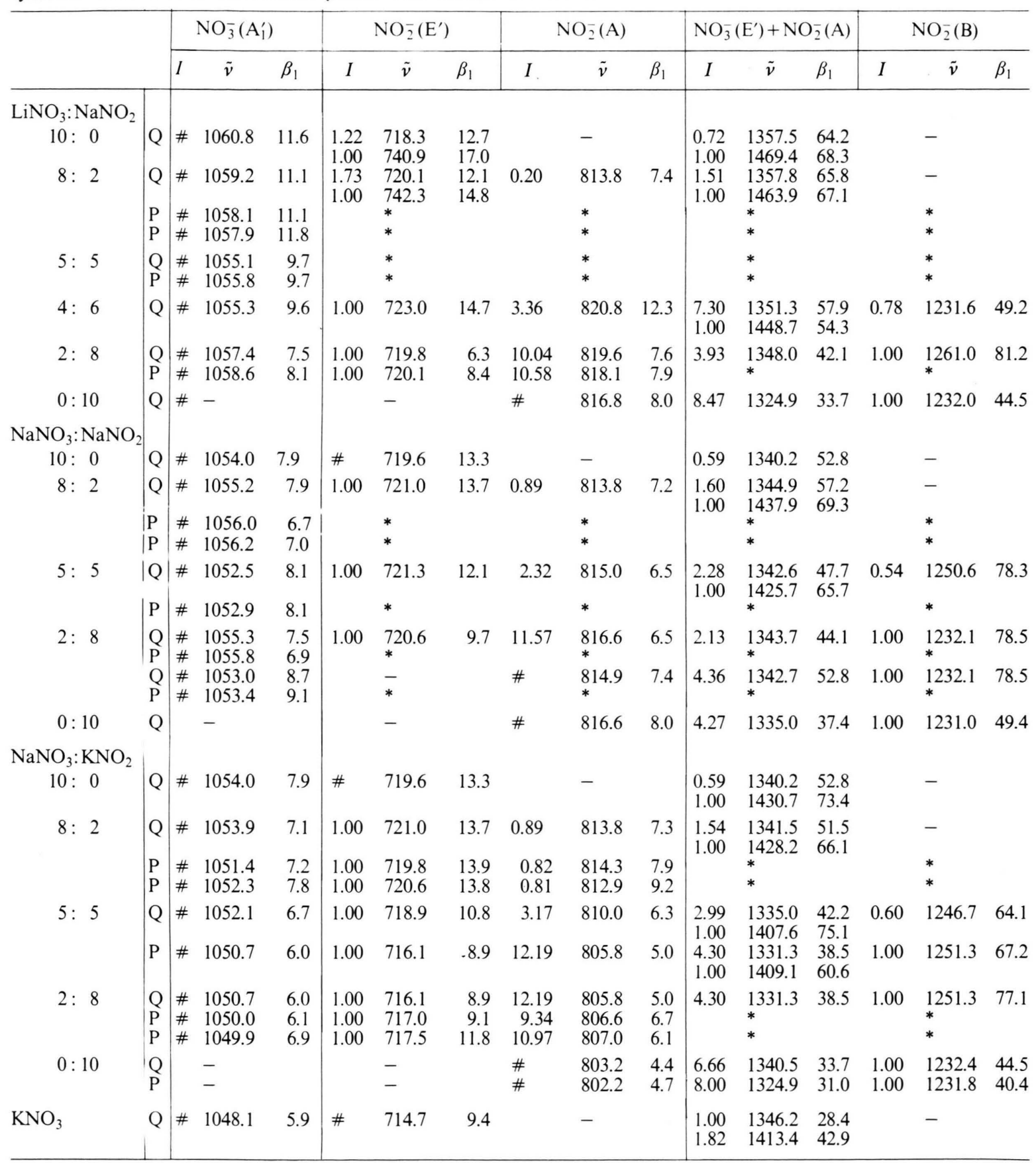




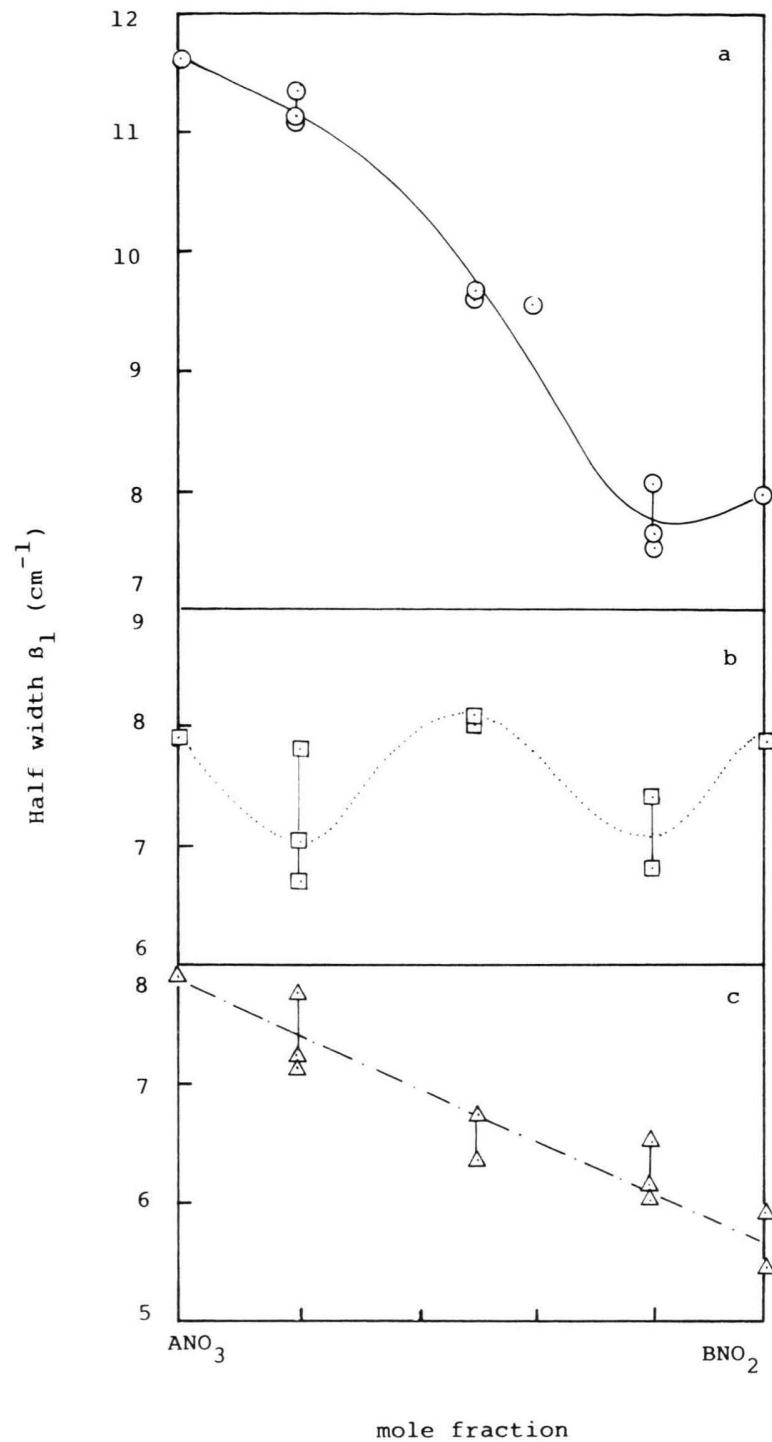

Fig. 3. Half width of $\mathrm{A}_{1}^{\prime}$ mode of $\mathrm{NO}_{3}^{-}$vs. mole fraction of molten $\mathrm{ANO}_{3}-\mathrm{BNO}_{2}$ systems.

a) $\mathrm{A}=\mathrm{Li}, \mathrm{B}=\mathrm{Na}$; b) $\mathrm{A}=\mathrm{Na}, \mathrm{B}=\mathrm{Na}$; c) $\mathrm{A}=\mathrm{Na}, \mathrm{B}=\mathrm{K}$.

Ubbelohde [22] explain this "red shift" as follows: the maximum absorption energy $E_{\max }$ is given by

$$
E_{\max }=E_{1}+\frac{h^{2}}{8 m r_{0}^{2}}
$$

where $E_{1}$ is the energy necessary for removing an electron from an anion, $h$ is Planck's constant and $r_{0}$ is a distance obtained by subtracting the cation radius from the distance between a cation and an anion, given by Wyckoff et al. [28]. Differentiation of (2) with respect to temperature $T$ results in

$$
\frac{\mathrm{d} E_{\max }}{\mathrm{d} T}=-\frac{h^{2}}{4 m r_{0}^{3}}\left(\frac{\mathrm{d} r_{0}}{\mathrm{~d} T}\right) .
$$

Since $r_{0}$ spreads with increasing temperature, $\mathrm{d} r_{0} / \mathrm{d} T>0$. Therefore $\mathrm{d} E_{\max } / \mathrm{d} T<0$, and the absorption spectrum shows "red shift" with temperature increase. Values of $E_{\max }$ obtained from our experiments were $236 \mathrm{~nm}(5.253 \mathrm{eV})$ at $260^{\circ} \mathrm{C}$, $240 \mathrm{~nm}(5.166 \mathrm{eV})$ at $360^{\circ} \mathrm{C}$ and $242 \mathrm{~nm}(5.123 \mathrm{eV})$ at $415^{\circ} \mathrm{C}$. They gave a quite linear function with temperature. Here, the value of $\mathrm{d} E_{\max } / \mathrm{d} T$ amounts to $-6.8 \mathrm{~cm}^{-1} \mathrm{~K}^{-1}$ for $\mathrm{NO}_{3}^{-}$in molten $\mathrm{NaNO}_{3}-\mathrm{NaNO}_{2}$. Rhodes and Ubbelohde showed that $\mathrm{d} E_{\max } / \mathrm{d} T=$ $-5.6 \mathrm{~cm}^{-1} \mathrm{~K}^{-1}$ for $\mathrm{LiNO}_{3}, \quad-3.4 \mathrm{~cm}^{-1} \mathrm{~K}^{-1}$ for $\mathrm{NaNO}_{3}$ and $-7.2 \mathrm{~cm}^{-1} \mathrm{~K}^{-1}$ for $\mathrm{KNO}_{3}$. Our value is twice larger than their value of $\mathrm{NaNO}_{3}$. In Fig. 6 a, $E_{\max }$ of $\mathrm{NO}_{2}^{-}$also shows a slight "red shift" as temperature increases. This fact indicates that $E_{\max }$ is not only to be assigned to the intramolecular $\pi-\pi^{*}$ transition in $\mathrm{NO}_{2}^{-}$[29] but also to the influence of the empty orbital of $\mathrm{Na}^{+}$. According to a calculation by the molecular orbital method [30], the highest occupied orbital of the $\mathrm{NO}_{2}^{-}$anion is known to be $-3.435 \mathrm{eV}(-0.1263$ Hartree). If the absorption

Table 2. Force constants of $\mathrm{NO}_{3}^{-}$calculated by an approximate method using a Urey-Bradley potential for each molten composition $\mathrm{ANO}_{3}: \mathrm{BNO}_{2} . K, H$ and $F$ are the stretching force constants, the bending force constants and those between non-bonding atoms, respectively.

\begin{tabular}{clll}
\hline & $\begin{array}{l}K \\
(\mathrm{mdyn} / \AA)\end{array}$ & $\begin{array}{l}H \\
(\mathrm{mdyn} / \AA)\end{array}$ & $\begin{array}{l}F \\
(\mathrm{mdyn} / \AA)\end{array}$ \\
\cline { 2 - 4 } $\mathrm{LiNO}_{3}: \mathrm{NaNO}_{2}$ & & & \\
$10: 0$ & 5.802 & 0.570 & 1.600 \\
$8: 2$ & 5.810 & 0.551 & 1.587 \\
$4: 6$ & 5.704 & 0.548 & 1.596 \\
$2: 8$ & 5.732 & 0.532 & 1.609 \\
$\mathrm{NaNO}_{3}: \mathrm{NaNO}_{2}$ & & & \\
$10: 0$ & 5.592 & 0.525 & 1.625 \\
$8: 2$ & 5.640 & 0.533 & 1.617 \\
$5: 5$ & 5.568 & 0.532 & 1.625 \\
$2: 8$ & 5.676 & 0.542 & 1.591 \\
$\mathrm{NaNO}_{3}: \mathrm{KNO}_{2}$ & & & \\
$8: 2$ & 5.579 & 0.529 & 1.628 \\
$5: 5$ & 5.470 & 0.511 & 1.656 \\
$2: 8$ & 5.421 & 0.500 & 1.660 \\
$\mathrm{KNO}_{3}$ & 5.401 & 0.519 & 1.599 \\
\hline
\end{tabular}


Intensity (arbitrary units)

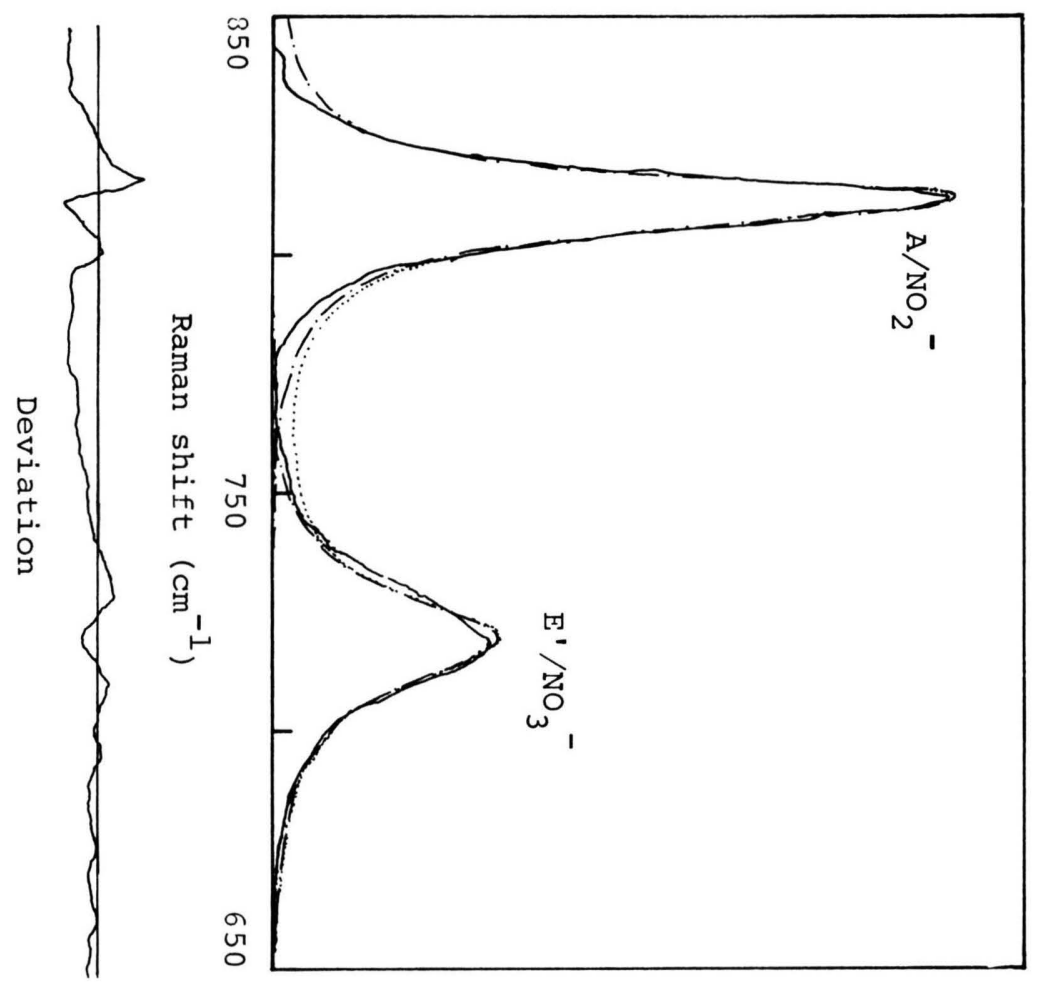

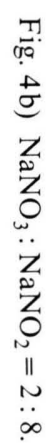

Intensity (arbitrary units)

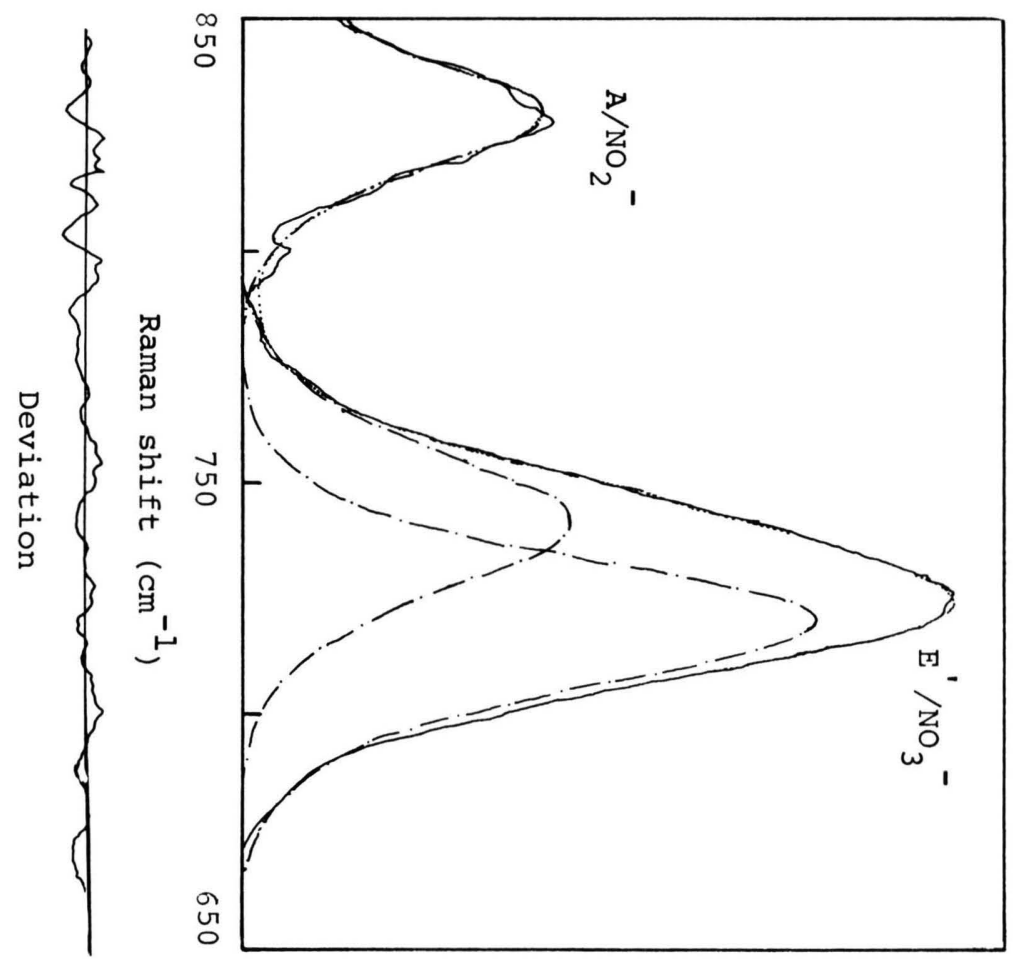

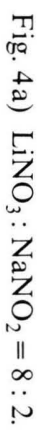




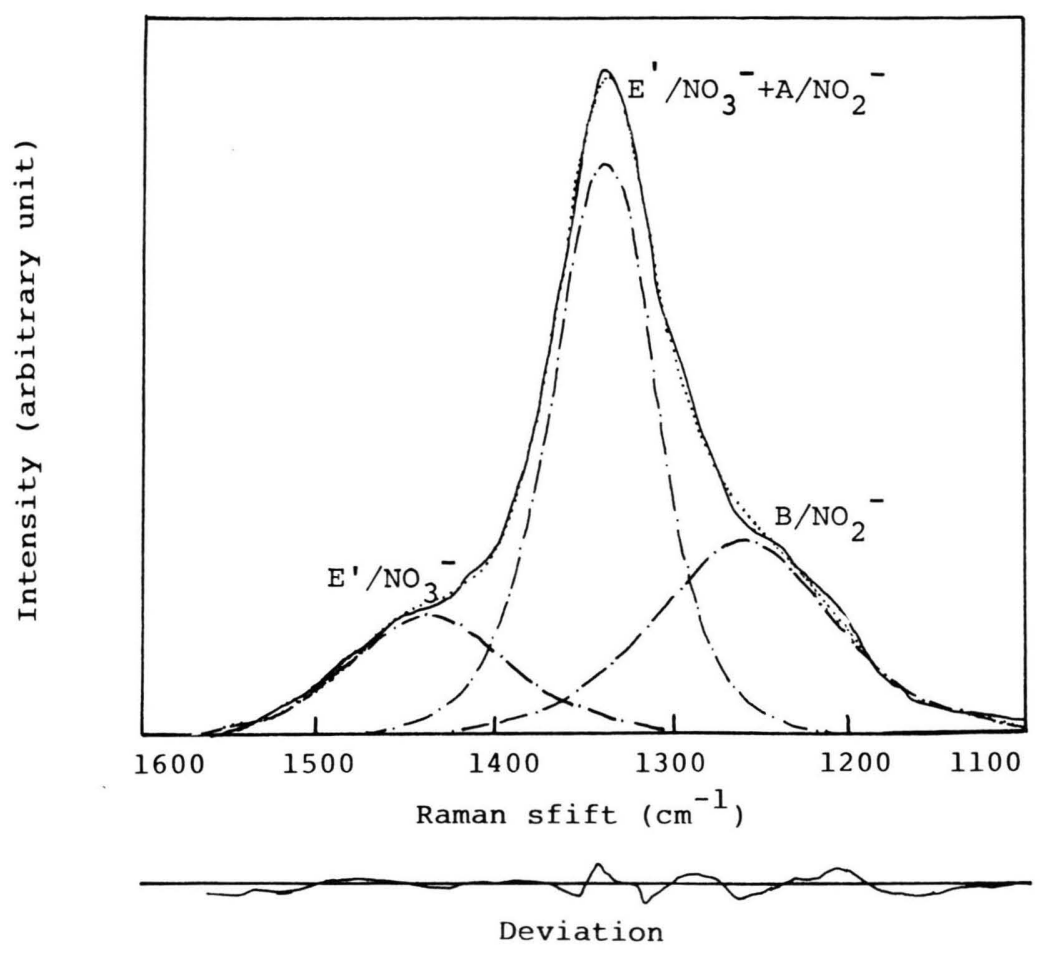

Fig. 4c) $\mathrm{LiNO}_{3}: \mathrm{NaNO}_{2}=4: 6$.

Fig. 4. Three examples of the deconvolution of Raman bands into individual modes by use of a nonlinear least squares method. Deviation of the observed Raman profile from the calculated profile are indicated below.

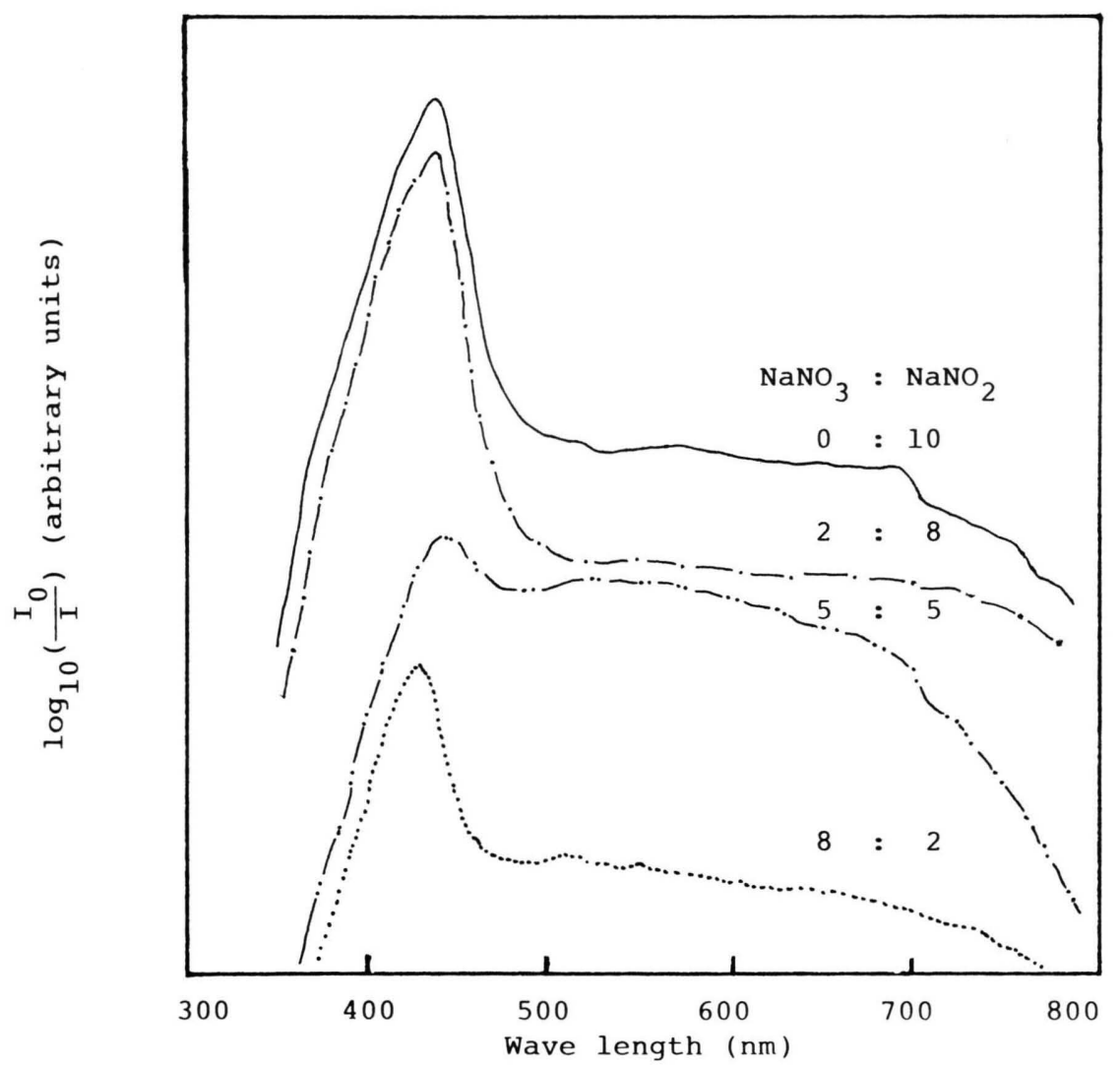

Fig. 5. Visible absorption spectra for various $\mathrm{NaNO}_{3}-\mathrm{NaNO}_{2}$ mixtures. 


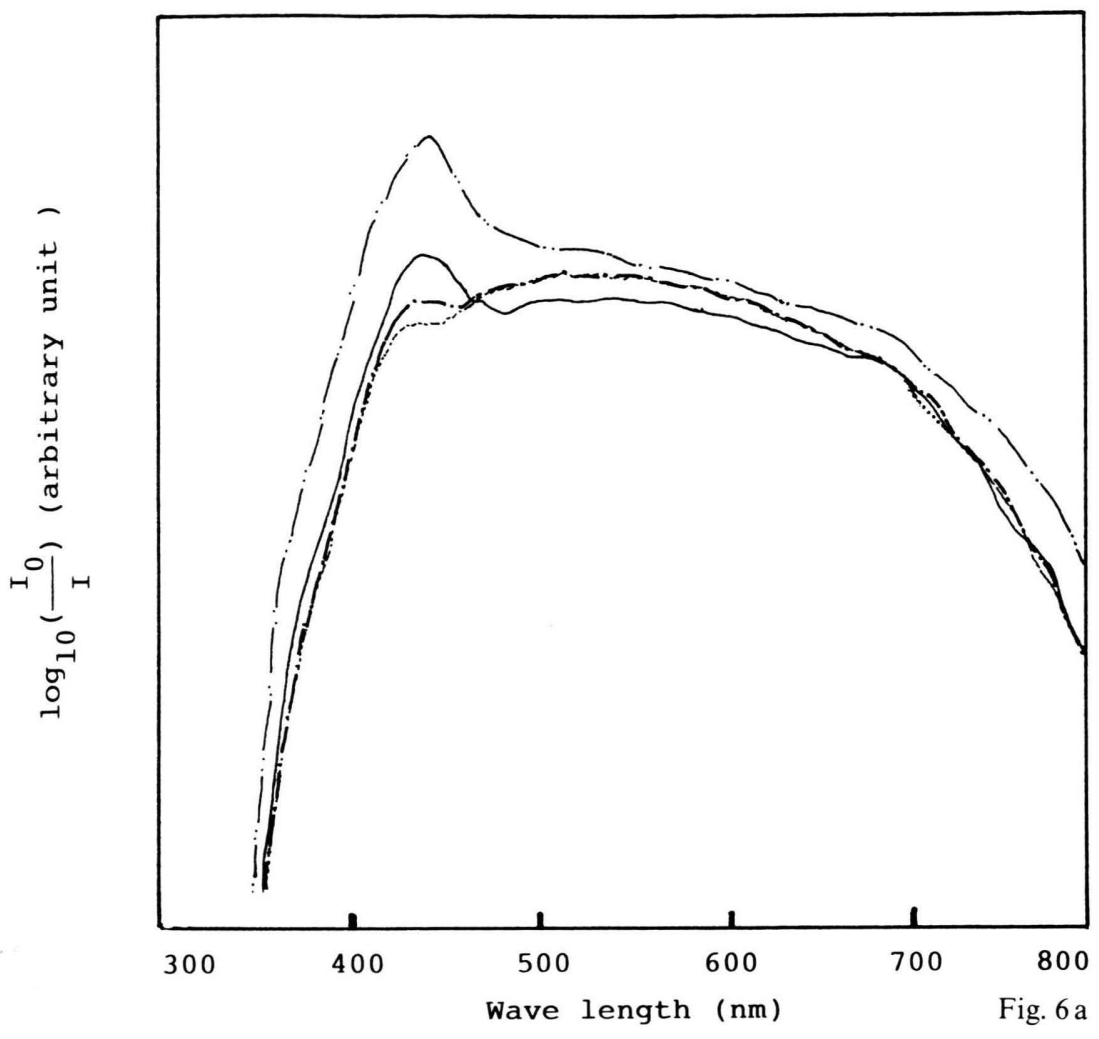

Fig. 6. Temperature dependence of visible absorption spectra (a) and ultraviolet absorption spectra (b) for the composition $\mathrm{NaNO}_{3}: \mathrm{NaNO}_{2}=5: 5$. $-\cdots-510^{\circ} \mathrm{C}$

$-410^{\circ} \mathrm{C}$,

… $260^{\circ} \mathrm{C}$.

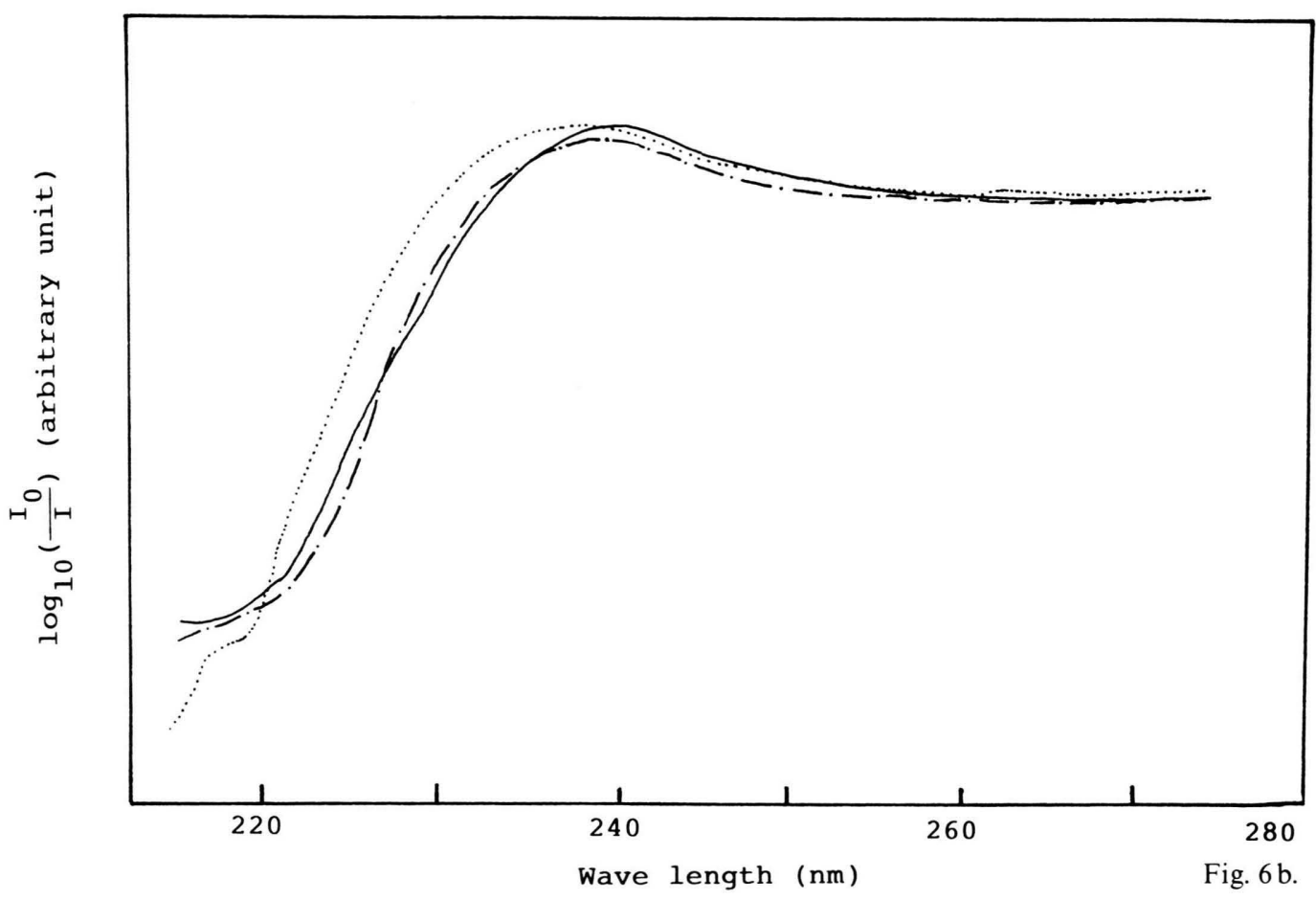




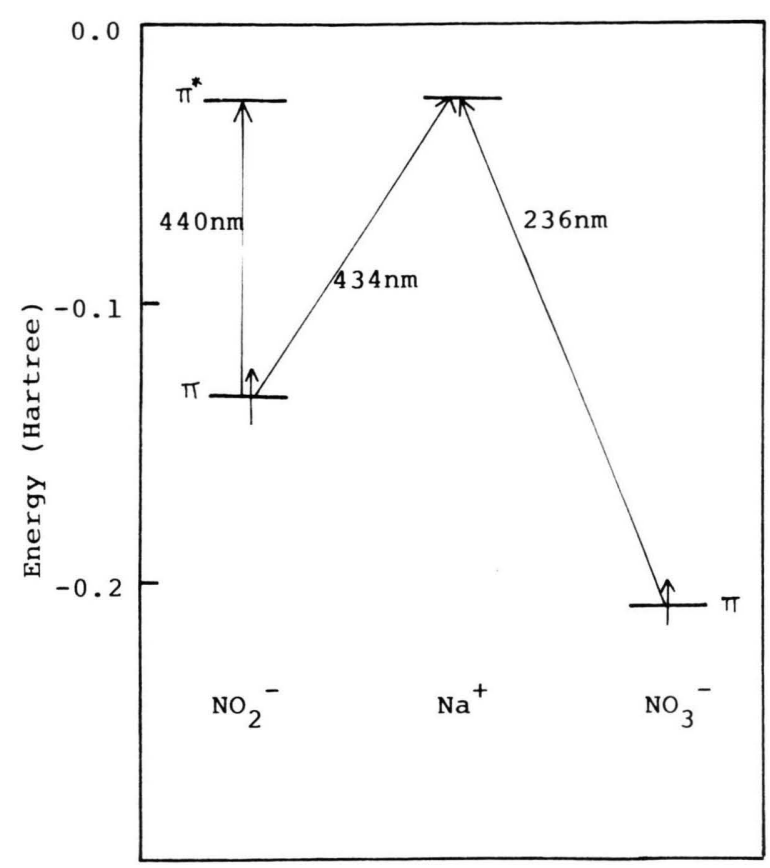

Fig. 7. Exprimentally estimated $\pi^{*}$ level of $\mathrm{NO}_{2}^{-}$and the empty orbital level of $\mathrm{Na}^{+}$in the molten $\mathrm{NaNO}_{3}-\mathrm{NaNO}_{2}$ system. the $\pi$ levels of $\mathrm{NO}_{3}^{-}$and $\mathrm{NO}_{2}^{-}$are based on calculations with the molecular orbital method [30].

$E_{\max }=440 \mathrm{~nm}$ is simply assigned to the $\pi-\pi^{*}$ transition in $\mathrm{NO}_{2}^{-}$, the energy level of the lowest unoccupied molecular orbital $\pi^{*}$ becomes $-0.617 \mathrm{eV}$ $(-0.022$ Hartree $)$. By use of the mentioned transition at $236 \mathrm{~nm}\left(260^{\circ} \mathrm{C}\right)$ in $\mathrm{NO}_{3}^{-}$, the energy level of the empty orbital of $\mathrm{Na}^{+}$can be determined to be $-0.578 \mathrm{eV}$, which leads to an energy difference of $2.857 \mathrm{eV},(434 \mathrm{~nm})$ between the empty orbital of $\mathrm{Na}^{+}$ and the highest occupied molecular orbital $(\pi)$ of $\mathrm{NO}_{2}^{-}$. As shown in Fig. 7, this energy difference $(434 \mathrm{~nm})$ is very close to the mentioned $\pi-\pi^{*}$ transition $(440 \mathrm{~nm})$, suggesting the existence of a strong interaction on approaching $\mathrm{Na}^{+}$to $\mathrm{NO}_{2}^{-}$in the molten system. Such energetic assignments in Fig. 7 are verified, because $\mathrm{Na}^{+}$coexists with $\mathrm{NO}_{3}^{-}$and $\mathrm{NO}_{2}^{-}$.

\section{Discussion}

No Raman shifts in the $\mathrm{A}_{1}^{\prime}, E^{\prime}\left(v_{3}\right)$ and $E^{\prime}\left(v_{4}\right)$ modes of $\mathrm{NO}_{3}^{-}$and the $\mathrm{A}$ and $\mathrm{B}$ modes of $\mathrm{NO}_{2}^{-}$ show any drastic composition dependences in $\mathrm{NaNO}_{3}-\mathrm{NaNO}_{2}$ melts (Figures $2 \mathrm{a}-\mathrm{c}$ ). The visible absorptions of $\mathrm{NO}_{2}^{-}$at $440 \mathrm{~nm}$ in Fig. 5 also undergo no appreciable shifts with composition. Therefore we conclude that the interaction between the anions, $\mathrm{NO}_{3}^{-}$and $\mathrm{NO}_{2}^{-}$, is much weaker than the ones between cations and anions. In other words, $\mathrm{NO}_{3}^{-}$ and $\mathrm{NO}_{2}^{-}$exist independently, and $\mathrm{Na}^{+}$may exist between them. The $\mathrm{A}_{1}^{\prime}$ mode of $\mathrm{NO}_{3}^{-}$in Fig. $2 \mathrm{a}$ shifts by about $2 \mathrm{~cm}^{-1}$ towards higher wave numbers and its half width (Fig. 3) becomes narrower. These small anomalies in molten $\mathrm{NaNO}_{3}-\mathrm{NaNO}_{2}$ have not yet been rigorously accounted for in the present situation. In the molten $\mathrm{NaNO}_{3}-\mathrm{KNO}_{2}$ system, each Raman mode shifts almost linearly with composition, as shown in Figures $2 \mathrm{a}-\mathrm{c}$. We conclude therefore that $\mathrm{NO}_{3}^{-}$and $\mathrm{NO}_{2}^{-}$are statistically surrounded by $\mathrm{Na}^{+}$and $\mathrm{K}^{+}$ions according to the $\mathrm{NaNO}_{3}-\mathrm{KNO}_{2}$ melt composition. The molten $\mathrm{LiNO}_{3}-\mathrm{NaNO}_{2}$ system differs from the other systems. Each mode of $\mathrm{NO}_{3}^{-}, \mathrm{A}_{1}^{\prime}$ and $E^{\prime}\left(v_{3}\right)$, and the A mode of $\mathrm{NO}_{2}^{-}$show a strong composition dependence, especially for the $\mathrm{A}_{1}^{\prime}$ mode of $\mathrm{NO}_{3}^{-}$. To elucidate these results, we enumerate the characteristic differences among $\mathrm{Li}^{+}, \mathrm{Na}^{+}$and $\mathrm{K}^{+}$as follows: Shannon's octahedral ionic radius [31] is $0.76 \AA$ for $\mathrm{Li}^{+}, 1.02 \AA$ for $\mathrm{Na}^{+}$and $1.38 \AA$ for $\mathrm{K}^{+}$. The volume occupied by a cation in the molten system is $0.439 \AA^{3}$ for $\mathrm{Li}^{+}, 1.06 \AA^{3}$ for $\mathrm{Na}^{+}$and $2.63 \AA^{3}$ for $\mathrm{K}^{+}$. The polarizing power of $\mathrm{Li}^{+}$is 1.85 , that of $\mathrm{Na}^{+} 1.1$ and that of $\mathrm{K}^{+} 0.75$ [32]. Judging from the differences enumerated above, the drastic composition dependence in Fig. $2 \mathrm{a}$, where a little amount of $\mathrm{LiNO}_{3}$ was mixed with $\mathrm{NaNO}_{2}$, can be explained as follows: there remaines some free space after subtracting the values occupied by $\mathrm{Na}^{+}$ and $\mathrm{NO}_{2}^{-}$ions from the total volume of the molten $\mathrm{NaNO}_{2}$ system. $\mathrm{Li}^{+}$would occupy this free space and attract several $\mathrm{NO}_{3}^{-}$anions to form a " $\mathrm{Li}^{+}$nitrate associate" in molten $\mathrm{NaNO}_{2}$, because $\mathrm{Li}^{+}$is smaller in size and stronger in polarizing power.

Smith and Boston [23] observed a "red shift" of the absorption maxima due to $\mathrm{n}-\pi^{*}$ transition in $\mathrm{NO}_{3}^{-}$at ca. $300 \mathrm{~nm}$ as the size of the cation increases from $\mathrm{Li}^{+}$to $\mathrm{Rb}^{+}$in the UV spectra of pure alkali nitrate melts. They explained this "red shift" on the basis of the Franck-Condon and conservationof-energy principles by showing that these $n-\pi^{*}$ transitions are strongly related to the charge density of the $\mathrm{N}-\mathrm{O}$ bond, and this shifts the electron density from the neighborhood of oxygen to that of nitrogen, and the strength of the $\mathrm{N}-\mathrm{O}$ bond in- 


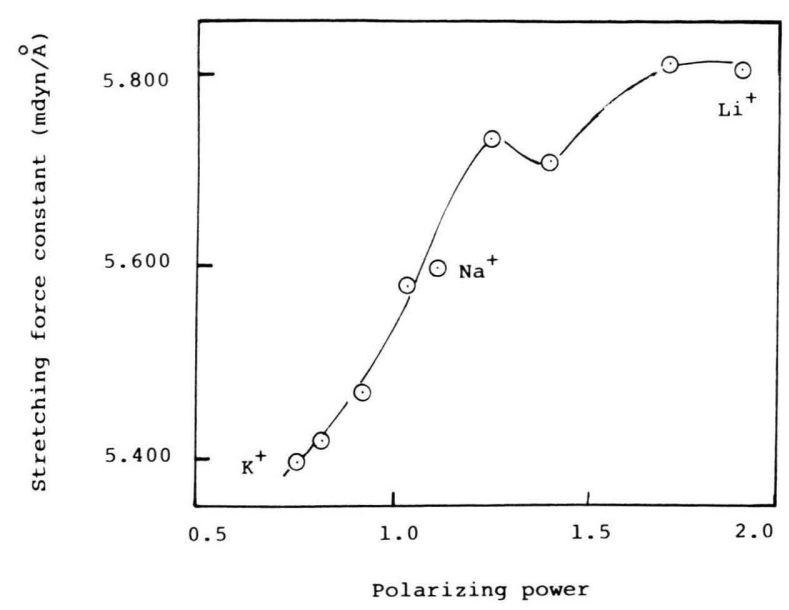

Fig. 8. Stretching force constant $K(\mathrm{mdyn} / \AA)$ in Table 2 vs. averaged polarizing power for the molten $\mathrm{ANO}_{3}-\mathrm{BNO}_{2}$ systems. $(\mathrm{A}, \mathrm{B})=(\mathrm{Li}, \mathrm{Na})$ and $(\mathrm{Na}, \mathrm{K})$.

creases as the size of the alkali cation decreases. Basing on this, the $\mathrm{n}-\pi^{*}$ transition in $\mathrm{NO}_{3}^{-}$strengthens the $\mathrm{N}-\mathrm{O}$ stretching force constant $K$, which is reflected in the Raman frequency $\tilde{v}\left(\mathrm{~cm}^{-1}\right)$ given by

$$
\tilde{v}=\frac{1}{2 \pi c} \sqrt{\frac{K}{M}}
$$

where $M$ is the reduced mass and $c$ is the speed of light. Thus, the Raman frequency shifts towards higher wave numbers as the size of the alkali cation decreases. In the " $\mathrm{Li}^{+}$-nitrate associate", since $\mathrm{NO}_{3}^{-}$ is strongly perturbed by $\mathrm{Li}^{+}$, the stretching force constant $K$ in the $\mathrm{N}-\mathrm{O}$ bond becomes stronger and the Raman frequencies shift to higher wave numbers for the molten composition $\mathrm{LiNO}_{3}: \mathrm{NaNO}_{2}$ $=2: 8$ in Figure $2 \mathrm{a}$. We can say that the shift of the $\mathrm{A}_{1}^{\prime}$ mode of $\mathrm{NO}_{3}^{-}$originates in the formation of " $\mathrm{Li}^{+}$-nitrate associate". With increasing $\mathrm{Li}^{+}$content towards the ratio $\mathrm{LiNO}_{3}: \mathrm{NaNO}_{2}=5: 5$, every $\mathrm{NO}_{3}^{-}$ or $\mathrm{NO}_{2}^{-}$is gradually shared by more than two $\mathrm{Li}^{+}$, and there are fewer localized " $\mathrm{Li}^{+}$-nitrate associates". Therefore the Raman shift of the $\mathrm{A}_{1}^{\prime}$ mode of $\mathrm{NO}_{3}^{-}$becomes smaller. As the concentration of $\mathrm{Li}^{+}$increases, the influence of $\mathrm{Li}^{+}$and $\mathrm{Na}^{+}$on $\mathrm{NO}_{3}^{-}$is averaged and homogenized with composition. The absence of the drastic composition dependence in the Raman shifts in molten $\mathrm{NaNO}_{3}-\mathrm{KNO}_{2}$ is due to the larger volume and the smaller polarizing power of $\mathrm{Na}^{+}$as compared to $\mathrm{Li}^{+}$. In Fig. 8 the stretching force constant $\mathrm{K}_{\text {of }} \mathrm{NO}_{3}^{-}$ is plotted against the averaged polarizing power of alkali cations in the molten system.

Anomalous changes with addition of small amounts of $\mathrm{Li}^{+}$to molten salts have also been observed in mobility measurements of $\mathrm{Li}^{+}$[33] or molecular dynamics simulations [34].

\section{Acknowledgements}

The authors wish to express their hearty thanks to Professor S. Maeda and Dr. S. Kobinata, Research Laboratory of Resources Utilization, Tokyo Institute of Technology, for their kind instructions and for permission to use their Laser Raman spectrophotometer. Thanks are also due to Professor I. Okada, Department of Electronic Chemistry, Tokyo Institute of Technology, for his useful discussions.
[1] O. J. Kleppa, J. Phys. Chem. 64, 1937 (1960).

[2] O. J. Kleppa and L. S. Hersh, J. Chem. Phys. 34, 351 (1961).

[3] O. J. Kleppa, J. Phys. Chem. 66, 1668 (1962).

[4] O. J. Kleppa and S. V. Meschel, J. Phys. Chem. 67, $2750(1963)$.

[5] F. G. McCarty, L. S. Hersh, and O. J. Kleppa, J. Chem. Phys. 41, 1522 (1964).

[6] G. J. Janz, U. Krebs, H. F. Siegenthaler, and R. P. T. Tomkins, J. Phys. Chem. Ref. Data 1, 581 (1972).

[7] S. Takeuchi and K. Furukawa, Proc. Int. Symp. Phys. Chem. Process Metallurgy (Pittsburgh), Part 1, 133 (1969).

[8] H. Ohno and K. Furukawa, J. Chem. Soc. Faraday Trans. 1, 74, 297 (1978).

[9] W. Bues, Z. Phys. Chem. 10, 1 (1957).
[10] G. J. Janz and D. W. James, J. Chem. Phys. 35, 739 (1961).

[11] J. K. Wilmshurst and S. Senderoff, J. Chem. Phys. 35, 1078 (1961)

[12] J. K. Wilmshurst, J. Chem. Phys. 39, 1779 (1963).

[13] S. C. Wait Jr. and A. T. Ward, J. Chem. Phys. 44, 448 (1966).

[14] S. C. Wait Jr., A. T. Ward, and G. J. Janz, J. Chem. Phys. 45, 133 (1966)

[15] J. H. R. Clarke, C. Solomons, and K. Balasubrahmanyam, Rev. Sci. Instrum. 38, 655 (1967).

[16] R. E. Hester and K. Krishnan, J. Chem. Phys. 46, 3405 (1967).

[17] D. W. James and W.-H. Leong, J. Chem. Phys. 51, 640 (1969).

[18] M. Peleg, J. Phys. Chem. 77, 2252 (1973). 
[19] J. H. Clarke, Chem. Phys. Lett. 4, 39 (1969).

[20] D. W. James and W.-H. Leong, Trans. Faraday Soc. 64, 1948 (1970).

[21] M. H. Brooker, J. Electrochem. Soc. 126, 2095 (1979).

[22] E. Rhodes and A. R. Ubbelohde, Proc. Roy. Soc. London A 251, 156 (1959).

[23] G. P. Smith and C. R. Boston, J. Chem. Phys. 34, 1396 (1960).

[24] V. A. Maroni and E. J. Mathaway, J. Inorg. Nucl. Chem. 34, 3049 (1972).

[25] P. I. Pretsenko and R. P. Shisholina, Russ. J. Inorg. Chem. 8, 1436 (1963).

[26] Y. Iwadate, K. Kawamura, and J. Mochinaga, J. Phys. Chem. 85, 1947 (1981).
[27] J. F. Kielkopf, J. Opt. Soc. Amer. 63, 987 (1973).

[28] A. R. Ubbelohde, The Structure of Electrolyte Solutions, ed. W. J. Harmer, Chapman \& Hall, London 1959.

[29] C. J. Ballhausen and H. B. Gray, Molecular Orbital Theory, p. 76, W. A. Benjamin Inc., New York 1965.

[30] J. F. Wyatt, I. H. Hiller, V. R. Saunders, J. A. Connor, and M. Barker, J. Chem. Phys. 54, 5311 (1971).

[31] L. H. Ahrens, Nature London 174, 644 (1954).

[32] R. D. Shannon, Acta Crystallogr. A 32, 751 (1976).

[33] C. Yang, R. Takagi, and I. Okada, Z. Naturforsch. 34 a, 498 (1979).

[34] F. Lantelme and P. Turq, J. Chem. Phys. 77, 3177 (1982). 